\title{
An Analysis of Sasak Language Maintenance and Shift in Sumbawa: A Case Study at Surya Bhakti Neighbourhood in Sumbawa Regency
}

\author{
Ridwan ${ }^{1}$ Hizbul Wathoni ${ }^{2}$ Hanofi Harianto ${ }^{3}$ \\ Selamet Riadi Jaelani ${ }^{4}$ \\ ridwanutan@gmail.com ${ }^{1}$ \\ hizbulwathoni96@gmail.com² \\ hanofikanjeng@gmail.com ${ }^{3}$ \\ selametriadijaelani ${ }^{4}$ \\ Universiti Sultan Zainal Abidin, Terengganu, Malaysia \\ Universitas Hamzanwadi
}

Received: November 2021

Accepted: November 2021

Online Published: Desember 2021

\begin{abstract}
This research aimed to investigate the Sasak language maintenance and shift of Sasak people in Surya Bhakti neighborhood. This research was Qualitative descriptive method was employed in analyzing the data. There were 40 participants divided into young generation participants and old generation participants. There are 20 participants of the young generations that consist of 16 males and 4 females, while 20 participants of the old generation participants consist of 18 males and 2 females. Three techniques were employed to collect the data: observation, interview, and documentation. Observation and interviews serve as primary data sources. Meanwhile, documentation serves as the secondary one. The process of the interview was recorded. Meanwhile, a field note was used during the observation. Documents or documentation were used to complete the data findings from the observation and interview and take some pictures in the research area. Thus, all data from observation, interview, and documentation were analyzed. The research results show that Sasak people, both young and old generation participants, are proud of their language and cultural identity. The young generation participants maintain the Sasak language in Surya Bhakti neighborhood. In addition, the young generation participants have the proficiency in speaking Sasak language fluently and accurately than Sumbawanese. Furthermore, the data indicate that the old generations of Sasak people in Surya Bhakti neighborhood are more likely to use Sasak language than Sumbawanese when communicating daily with Sasak people in their community, even in their community outside of the neighborhood.
\end{abstract}

Keywords: Diary, Writing, Students' Ability

\section{Introduction}

Acording to (Purwoko, 2016), Indonesia administratively has 34 provinces consisting of some regencies in each province. It is divided into 416 regencies, 98 cities, 7024 sub districts and 81625 villages. It means that Indonesia has a lot of vernacular languages that are used by the indigenous of people. Furthermore, there are four regencies which are included into Sumbawa Island i.e. west Sumbawa regency in the west part of the island; Sumbawa; Dompu; and Bima in the east part of the island (Jazadi \& Widari, 2019).

There are several locations of Sasak people transmigrating in Sumbawa. One of the transmigration locations is at Surya Bhakti neighbourhood which belongs to Pekat in Sumbawa sub district. Thus, the population of Sasak people in this location is the largest one. It has about 6305 people who have separated out in several neighbourhoods in the village. In addition, the number of Sasak people is about 1095 people. Furthermore, Surya Bhakti neighbourhood 
becomes an economic centre in Sumbawa, because most of the people have more contribution in some commercial activities in certain traditional markets such as "Sketeng" which is the biggest market in the Sumbawa regency. They work as the seller of vegetables, spices, gold, clothes etc. (Dana, 1999).

Language maintenance relates to attitude toward certain language to be used consistently among other languages in a community or region (Bianco, 2017). Then, language shift relates to speaker of certain language in mobility's problems (Prochazka \& Vogl, 2017). It can cause language shift in several domains of community or region, which the first time speaks by using mother tongue then change to other language. It means that the mother tongue or the first language in the community of bilingual or multilingual society, shift to other language. Language maintenance and shift are very important to study in order to acknowledge the language problems in several communities of society (Matras, 2020).

There is some research about language maintenance and shift which was done by several others scholars. (Harnish, 2011) states language minority, ethnic identity, and language maintenance with a case study of Sumbawanese in Lombok. He did the research about language maintenance of Sumbawanese in Lombok. Furthermore, in 2010 he did research about language maintenance and stable bilingualism at the Sasak language speaker in Lombok. His scopes of the study were family domain, neighbour, kinship, and certain domain, even percentage data indicated that Sasak language is their mother tongue and it remains to be maintained. On the other hand, the same research was done overseas as what (Kuncha \& Bathula, 2004) did about the role of attitude in language shift and language maintenance in a new immigrant community in New Zealand. In line with it, (Habtoor, 2012) did research about language maintenance and shift among second generations of Tigrinya speaking Eritrean immigrants in Saudi Arabia.

Based on the facts above, the present researcher was interested in conducting this research about the language maintenance and shift in Surya Bhakti neighbourhood which belongs to Sumbawa sub district, Sumbawa Besar Regency of West Nusa Tenggara Province. In addition, the researcher wanted to identify more details about the probability of shifting from Sasak language to Sumbawanese. Furthermore, the present researcher wished to elucidate the language use among the young generations in their daily communication. The main aim of this research is to investigate the Sasak language maintenance and shift of Sasak people in Surya Bhakti neighbourhood.

\section{RESEARCH METHOD}

The method of this research was qualitative descriptive method which focused on describing the phenomenon based on the research area. According to (Pong, 1998), qualitative research is defined as multi-method in focus, involving an interpretive, naturalistic approach to its subject matter. This means that qualitative researchers study in their natural settings, attempting to make sense of interpret phenomena in terms of the meanings the people bring to them.

There were 40 participants in this research. The participants were divided into young generation and old generation of Sasak people in Surya Bhakti neighbourhood. There were 20 participants of the young generations that consist of 16 males and 4 females. Meanwhile, there were 20 participants of the old generations that consist of 18 males and 2 females. To collect 
the data, three techniques were employed namely observation, interview, and documentation. Observation and interview serve as primary data sources. Meanwhile, documentation serves as the secondary one. The process of interview is recorded. Meanwhile, field note was used during the observation. Documents or documentation are used for completing the data findings from the observation and interview and taking some pictures in the research area. Thus, all data from observation, interview, and documentation were analysed. In addition, the present researcher used data analysis of interactive model to analyse the data. It consists of data reduction, data display, and verifying or making conclusion.

\section{RESULTS ND DISCUSSION}

\section{a. The General Descriptions of the Observations and Interview Activities}

The first day of research was on Monday, November 28, 2017. The researcher did observation and met the leader of Surya Bhakti neighbourhood, which is administratively included to RW 08 (Rukun Warga) in Pekat Village of Sumbawa regency. Rukun warga is the upper unit of village, which consisting of several RTs. He was Mr. H. Faizun that became one of active participant in this research. As the leader, he knew well all about his society, language, and cultural activities of Sasak people in this neighbourhood. He led four RT (Rukun Tetangga) or the minimal unit of a village. In addition, he suggested me to meet each of rukun tetangga's leaders in order to get more information about the society before interacting directly. The present researcher spent much time in his house in order to observe and interview him regarding to the researcher's research. Additionally, for more detail information about the participants can be seen in the next sub-chapter.

In the second day, the present researcher met each of rukun tetangga's leaders and interviewed them one by one more deeply. The researcher did it based on the purposive sampling way to collect the research data. Finally, one of them suggested the researcher to meet a person that became Pemangku Adat (one who knows more detail about ethnic, language and cultural identity of particular community in a society), hopefully could help the researcher to know more deeply about Sasak people in the research place. Fortunately, the researcher met him and discussed about language use, the level of Sasak language. Next, the researcher tried to discuss about the pride of Sasak people in Surya Bhakti neighbourhood of their language and cultural identity, as one of his responses when interviewing him as cited below. [1] "Oh sangatbergune, leq lingkungan niki, khususnya lingkungan surya bakti, bareh mun ariq mlet begelining jalan-jalan bahasa yang di dengar gak ada yang lain, base Lombok toq sampai terkesan maraq-maraq idap te leq Lombok timur idap te. Karena di setiap pojok kampung ini menggunakan base daerah nte yaitu base Sasak, tapi orang yang baru masuk nda ada rasanya saya di Sumbawa ini kayak di Lombok ne ehhhh kalau orang baru masuk di kampung ini begitu rasanya"'(Interview with one the old generation participants) 
[Oh it is very useful in this neighbourhood, especially Surya Bhakti neighbourhood, later if you have wish to traveling only Sasak language you will hear, no other languages. Only Sasak language, until you think that you in east Lombok right now. Because, in every corner of this neighbourhood use vernacular language, it is Sasak language, but every new comer enters this neighbourhood, they do not think live in Sumbawa. It likes in Lombok ehhh. When new comers come here the sense like that].

Based on the statement above, the researcher assumed that the Sasak people in Surya Bhakti neighbourhood still have pride of their language and cultural identity. It can be discerned from of all of the society there who always use the Sasak language. Moreover, the new comers said that they were not in Sumbawa but in east Lombok of Lombok Island. Surely, it was not enough to make a conclusion about it by only perceiving the statements of a person. However, it was merely two days of research time. But it almost represented all the results of data collection.

To make conclusion of this research, the researcher collected more data and spent much time in it. Then, the researcher analysed the data collection by reducing the unimportant data and displaying it to acknowledge the fact of phenomena which was concluded as the result of entire research. Finally, the researcher gained the data. It was analysed based on the method stipulated before in the previous chapter. The results were outlined after the next sub-chapter below.

\section{b. The Pride of Language and Cultural Identity of Sasak People in Surya Bhakti Neighbourhood}

To acknowledge the pride of language and cultural identity of Sasak people in Surya Bhakti neighborhood, the researcher asked both of the young generations and old generation participants about the last item. It was about language identity which consists of 8 questions. Furthermore, the questions were number 12 to 18 which was responded by the participants with words "bergune" and "perlu". The word "bergune" means that the participants agreed with the questions that asked by the researcher. In the question 12 for example, the participant YG.1 responded "bergune". The question was delivered in Sasak language "Ape base Sasak bergune kadu ngeraos kance dengan toaq leq ite? Kumbeq ne? "[Is speaking Sasak language generally useful for talking with elders Sasak people? why?]. In addition, the participants responded on the question by following their reasons on it, but the researcher only put the word "bergune" in order to make it easy to understand in the table. Meanwhile, in the quotations of the interview, the researcher put it completely. To know more detail about the questions and responses of the participants. The participants conveyed various reasons about it, as verbalized by some of participants below. [2] "Bergune, karena lueq dengan toaq tene base Sasak doang kadu ne. adeq ne becat ngerti"'(Interview with the YG.1) [It is useful, because most of old people here use Sasak language that understands quickly].

Besides, all of the participants were asked about their responses to the statement 13. It was about "is speaking Sasak language generally useful for maintaining Sasak people's 
culture? Why?" Entirely, all of the participants responded that speaking Sasak language was very useful to maintain their language as well as their culture identity. They did not want to shift their language with other, because of their pride to their language. Particularly, to use Sasak language in their family was their purpose. In addition, the Sasak language was their vernacular from their great-grandparents that had to be maintained even though they lived in other place of their local language island, as indicated by one of the participants below.

[5] "Amun kite jak base Sasakbergune jagaan terutama le keluargaante, sangat bergune sengak ne wah lengan nenek moyang nte le dengan Sasak"(Interview with the YG.2) [Sasak language is important to maintain especially in our family, it is really important because it is from our great-grandparents are Sasak people]. Thus, to have communication with Sasak people they used Sasak language. Meanwhile, when having communication with other ethnics used Indonesian predominantly, as cited from their verbalization below. [8] "Tergantung, mun ne dengan siq te bebase Sasak yate kadu base Sasak, mun base Sumbawa ya kadu base Sumbawa" (Interview with YG.2) [It depends to whom we are talking, when talking to Lombok people we use Sasak language, to Sumbawanese people we use Sumbawanese]. [9] "Tergantung batur te begawain si, mun batur Lombok dengan te begawaian te kadu base Sasak, mun dengan Sumbawa te kadu base Sumbawa atau Indonesia"(Interview with the YG.7) [It depends on our friend, when our friend is Lombok people we communicate by using Sasak language while to Sumbawanese people we use Sumbawanese or Indonesian].

Furthermore, Sasak language was useful for traveling around the Surya Bakti neighborhood, as indicated in the statement 15 above. It was caused by some reasons of the participants. Those were almost all of people in Surya Bhakti neighborhood were Sasak people that used Sasak language as their vernacular language and they did not use Sumbawanese or Indonesian for communication to their community. If they met Sumbawanese people and other ethnics, they would use Sumbawanese or Indonesian for communication.

The Sasak language, in addition, was generally useful for helping Sasak people who monolingual in Surya Bhakti neighborhood. It can be seen from the statement 16 in the table above. All of the participants responded that it was useful to it, as verbalized by one of the participants below. [13] "Bergune, base Sasak. Kan ngak ne taoq base lain selain base Sasak doang" (Interview with the YG.1) [The Sasak language is useful, because no other languages that they know except Sasak language].

The most important thing of the results, furthermore, was Sasak language maintained and prided by the number of Sasak young generations in Surya Bhakti neighborhood. It can be discerned from the table above at statement 17 that all of the young generation participants agreed to Sasak language to be maintained. It means that the young generations in Surya Bhakti neighborhood maintain and pride of their Sasak language. One of the participants indicated his response as below. [15] "Mun ite jaksangat perlute jage, ya karna base sendiri, istilah ne bahasa ku idola ku lah. Dengan cara te terapang lek anak-anak nte” (Interview with the YG.5) 
[It is really important to maintain, because it is our language. We can call that my language is my popular idol, by using it to our children or the next generations].

In addition, they did not want to shift their language to another language or let it not to be used by the native speakers of Sasak language in this neighborhood. Furthermore, the young generations had intension to speak Sasak language wherever they were by using it correctly and confidently, as cited from interview with the YG.16 below.

[16] "Perlu, soal ne base kance budaya Sasak harus te lestariang. Care ne te berahase dengan baik sak kena lek lingkungan masing-masing....harus te ajahin jok generasi seterusnya" (Interview with the YG.13) [It is necessary to maintain. The Sasak language and Sasak culture require to be maintained by using applying it correctly in our neighborhood and have to be taught to our next generation].

The last, the number of Sasak young generations in Surya Bhakti neighborhood was interested to attend various cultural activities in Sasak language such as rituals and marriages. It was as a way to maintain their Sasak language and cultural identities. It is obviously showed in the table above on statement 18 in which a number of young generation participants indicated their agreement on their responses on it as responded by two of the participants below.

[20] "Perlu sih. Perlu te hadiri, karena base te kadu leq acare-acare maraq noh sebagian besar te kadu base Sasak.....base alus Sasak. Ya perlu te hadiri untuk te njage base Sasak nih" (Interview with the YG.4)

[It is useful to attend the ceremony, because most of the language use in the ceremony is Sasak language. it is more likely to use the formal language of Sasak language. The Sasak language is necessary to maintain]. [21] "Perlu, sengak lueq acara adat Sasak ngadu base Sasak, jari, perlu te hadiri untuk upaya menjage base Sasak niki" (Interview with the YG.19).

[It is useful to attend, because some of the ceremonies of Sasak culture communicate by using Sasak language. So, it is required to be attended as a way to maintain the Sasak language].

To acknowledge the pride of language and cultural identity of Sasak people in Surya Bhkati neighborhood, furthermore, the researcher asked the old generations' participants about their language and cultural indentities. The findings were almost same with the young generations' responses.

All of the old generation participants responded to the statement 12 that speaking Sasak language is useful for talking to elders Sasak people. Furthermore, all of the old generation participants said that speaking Sasak language generally useful for maintaining Sasak culture. It can be shown in the table above on the statement 13 that they agreed about it, as the participant OG.19 responded [25] "base Sasakbergune te kadu dalam te njage base kance budayante" [Sasak language is useful to use in maintaining our language andculture].

Furthermore, the old generations had program to maintain Sasak language by teaching the language to their young generations in order to comprehend the language more detail. To recognize the level of Sasak language was one of their intension in maintaining the language, as indicated by the OG.4 when interviewing process below. 
[30] "Sangaat perlu, kebetulan karena saya di sini ditunjuk sebagai pemangku adatnya. Mewarisi ke adek-adek generasi muda, embe iye bahasa Sasak sak asli, ahhh bahasa Sasak yang asli salah satu contoh, bahasa Sasak yang kita dengar ini kan terdiri dari 3-4 tingkatan salah satu contoh kata mangan ini kan umum, eee orang Sumbawa juga bilang kalau makan itu mangan nah tapi kalau mangan base Lombok kita berikan kepada adek-adek yang masih kecil dari kita yang ngomong, ye tebasean mangan. Amun usia pade-pade ite bahasekan lebih halus ngelor, lamun leq dengan sak toaqan malik kita bahasakan yang lebih halus lagi medahar. Inilah, ne tak ajerang jok genrasi muda adeq ne taoq mbe base Sasak sak asli, jadi sangat-sangat begune" (Interview with the OG.4) [It is very important. I was chosen as the Pemangku Adat here. To teach to the young generations whether Sasak language that pure or not was one of my responsibility. For instance Sasak language that we use consists of 3 to 4 level. The word "mangan" is general, Sumbawanese also say "mangan" for eating. But the mangan word in Lombok is used to young people. While to the same age use cultured language "ngelor' and to the old people then the speaker use "medahar". This is that necessary to teach to our young generations hopefully can know whether the pure Sasak language or not. Thus, it is very important to maintain the Sasak language]. [31] "Ya jelaslah sengak ite kan ye budayente istilah ne kan, base Sasak ne ya perlu kita jage dengan care terus te kaduang leq anak-anak nte"(Interview with the YG.20) [Yes it is, of course, because this is our culture. Sasak language is necessary to be maintained by using the language to our children]. [32] "[....] Perlu gati, sengak leq acare perkawinan sebagai contoh, araq namanya upacara sorong serah aji kerame yelah tugas pembayun atau pemangku adat ne sak pendengahan jok masyarakat ramai oh ne ye base Sasak sak asli [...]"(Interview with the OG.4) [The Sasak language is really necessary to maintain, because in the marriage ceremony for instance, there is a giving dowry ceremony. One of the duties of the Pembayunor Pemangku Adatis to present to society whether the real or pure of the Sasak language in the ceremony]. Based on all of the data shown on the table 4.3 and 4.4 above, the young generation participants and old generation participants were proud of their Sasak language and cultural identity.

\section{c. The Maintenance of Sasak Language by the Young Generations of Sasak People in Surya Bhakti Neighborhood}

Furthermore, all of the young generation participants preferred to use Sasak language to their family at home domain. They communicated with their family at home by using Sasak language because all of the family members were Sasak people that speak Sasak language fluently. One of the participants verbalized their responses as below.

[35] "Base Sasak, ye kebiasaan leq tene kan base Sasak selapuq ne te kadu bilang jelo" (Interview with the YG.5) [Sasaklanguage, it is our habit to use Sasak language here.All of us use Sasak language everyday].

Based on the statement 7 on the table 4.5 above, all of the young generation participants usually spoke Sasak language to their friends at home. The participants responded that they 
preferred to use Sasak language because almost all of their friends that came to their home were Sasak people. However, it was usually because it depended on to whom they were speaking. When talking to Sumbawanese friends, sometimes they used Sumbawanese. Meanwhile, speaking to the other ethnic groups used Indonesian. However, they sometimes preferred to use Sasak language, as responded by the YG.11 and YG.19 below. [39] "Kadang-kadang baseindonesia, karna sudah terbiasa sejak kecil"'(Interview with the YG.11) [I sometimes use Indonesian, because it is our habit since childhood]. [40] 'BaseSasak, lagu' kadang-kadang base Indonesia, sengak seringan wah te kadu base Indonesia dengan batur-atur leq sekolah"(Interview with the YG.19) [I speak Sasak language, but sometimes speak Indonesian. It is because I often use Indonesian to friends at school].

There were three questions that were asked to the participants. It was statement 9, 10, and 11. The statement 9 was about the language use by their parents whether they generally spoke Sasak language to the participants or not. Meanwhile, the statement 10 was about the language use by the participants whether they generally communicated by using Sasak language to their parents or not. The last, the statement 11 was asked whether the young generation participants generally used Sasak language or Sumbawanese when thinking or talking to themselves when they were in public domain.

There were 17 out of the 20 participants who responded to the statement 9 that their parents used Sasak language when talking to them in the public domain. There were 2 out of the 20 participants responded that sometimes their parents used Sasak language and Indonesian to them when having communication in public domain. There was 1of the participants responded that his parents used Indonesian to him. It was because of his parents who usually used Indonesian to him since his childhood. However, when having communication to his friends in public, he preferred to use Sasak language.

Furthermore, the young generation participants replied on the statement 10 that almost all of them speak Sasak language to their family in the public domain. They were the 17 out of 20 participants who replied on the statement 9 above in which their parents spoke Sasak language to them in the public domain. 2 out of the 20 participants sometimes spoke Sasak language, Indonesian and Sumbawanese a little to their family in the public domain. Besides, 1 out of the 20 participants spoke to his family by using Indonesian in the public doamin. 1 out of the 2 participants who responded usually used Sasak language and Indonesian verbalized as below. [41] "Kadang baseSasak kance Indonesia, karna niki istilah tergantung pandangan keluarga. Niki Alhamdulillah dengan toaq niki tetoaq'an ngeno ape arenna tokoh agama. Jari campuran ne kadu, araq base Indonesia, Sasak kance Sumbawa"(Interview with the YG.16) [Sometimes, I use Sasak language and Indonesian, because it depends on family's point of view. Here, Alhamdulillah my parents is respected by the society. They become religion prominent figure. That is way we are mixing the language use, sometimes Indonesian, Sasak language, and Sumbawanese]. 
It can be inferred that most of the young generations of Sasak people in Surya Bhakti neighborhood preferred to use Sasak language when they think or talk to themselves when at home and public domain. It means that the young generations of Sasak people in Surya Bhakti neighborhood maintain their Sasak language.

\section{d. The Proficiency of the Sasak Young Generations in Surya Bhakti Neighborhood in Using Both Sasak Language and Sumbawanese}

All of the participants were indicated in the statement 1 that they understood Sasak language fluently than Sumbawanese. However, some of the participants understood Sumbawanese a little bit, as verbalized by one of the participants below.

[43] "Alhamdulillah lancar ngertian base Sasak daripade base Sumbawa, soalkan base Sasak ne salah seke budayante kan dengan Lombok. Jadi...mun base Sumbawa ya sekedi lancer lagu' ndek selancer base Sasak"(Interview with the YG.16)

[All praise is to Allah.I more understand Sasak language than sumbawaese, because the Sasak language is our vernacular language of Lombok people. But, I speak Sumbawanese fluently but not as fluent as the Sasak language].

Besides, all of the participants answered on the statement 2 that they spoke Sasak language fluently than Sumbawanese. It was because the Sasak language was their vernacular language which always used in the neighborhood. The responses were almost same to the statement 1 above that some of the young generation participants could speak Sumbawanese, as indicated by the YG.13 when interviewing, [44] "lanceran sih base Sasak. Lagu' taoq si base Sumbawa sekedi-kedi cuman susah te sugulan waktu nte ngeraos" [I speak Sasak languagemore fluent than Sumbawanese, but I know Sumbawanese a little bit. It is only difficult to say].

\section{e. Language Use of the Sasak Old Generations in Surya Bhakti Neighborhood in Their Daily Communications.}

There were 8 of the old generations on statement 5 did not have answer because some of reasons. It was because some of their parents had died and still lived in Lombok Island as the beginning of life of Sasak people. Next, the 12 out of the 20 participants who still have parents in this neighborhood claimed that their parents always spoke Sasak language to them at home domain, as verbalized by one of the participants [46] "Mun base Sasak jak enggak nya mun dengan toaq te kan. Ya kadu base Sasak"(Interview with the OG.13). It means that the parents of the Sasak old generation participants in Surya Bhakti neighborhood only speak Sasak language to their children even all of their families.

In line with it, that almost all of the old participants always spoke Sasak language to their parents and families at home domain were result of the statement 6 above. Meanwhile, 4 out of the 20 participants usually used Sasak language, Sumbawanese or Indonesian when speaking to all of their families at home domain. It was only in particular situation such as teach their children to speak Indonesian because of school necessary only. However, they more likely preferred to use Sasak language at home domain, as one of them indicated his response [47] 
"Ya campuran base Sasak kance base Indonesia lagu'Sasak siq lebih dominan te kadu. Raterate sebagian besar ngenoh wah" (Interview with YG.9). It shows that generally some of the participants who usually use Sasak language and Indonesian preferred to use Sasak language.

In statement 9 some of the participants did not have parents and some of their parents spoke Sasak language to them in public domain. Additionally, they preferred to use the formal style of the Sasak language. Thus, when talking to Sumbawanese people sometimes they used Sumbawanese, as indicated by one of the participants below. [48] "Base Sasak, tapi basente base halus. Kadang base betiang berenggeh. Mun leq luah kance dengan Sumbawa kan kita ngikutin dengan nte, mun dengan Sumbawa dengan te ngeraos te kadu base Sumbawa" (Interview with the OG.8) [I speak Sasak language, but the formal style of Sasak language. Sometimes I speak betiang berenggeh. When talking outside of this neighborhood, I use Sumbawanese or Indonesian].

Furthermore, in the statement 10, all of the participants used Sasak language when talking to their families in Surya Bhakti neighborhood even outside of the neighborhood. It was as said by the OG.5 [49] "Jelas te kadu base Sasak leq julun dengan rame kance keluarge. Ya walaupun di luar lingkungan nih tetap te kadu base Lombok" [Of course, we use the Sasak language when speaking in the public domain with families, even outside of this Surya Bhakti neighborhood].

Additionally, all of the participants used Sasak language when thinking or talking to themselves when they were in public doamin. It can be seen on the statement 11 in table 4.9 above. Generally, all of the Sasak young generations and old generations of Surya Bhakti neighborhood used Sasak language when thinking or talking to themselves when they were at home and public domain. One of the participants responded it as below.

[50] "Ya ngadu base Sasak, nka te berpikir atau ngeraos leq julun dengan rame, tulak maren base baru karna ite mayoritas Lombok leq ite ya otomatis berpikir dan bertindak, berbicarapun te kadu base Sasak" (Interview with the OG.4)

[Yes we are. We use Sasak language for tinhkning or talking to ourselves in the public domain. As we say before that Sasak people is mayority here. That is way automatically we think or talks use the Sasak language].

From the data shown above, finally, the present researcher claims that the old people in Surya Bhakit Neighborhood more likely to use Sasak language than Sumbawanese when having daily communication in their community, even outside of the neighborhood.

\section{CONCLUSION}

Based on the results of the analysis in the previous chapter, there are four conclusions that can be taken in this research: The first, both of the young generations and old generations of Sasak people in Surya Bhakti neighbourhood are proud of their Sasak language and cultural identity. The second, Sasak language in Surya Bhakti neighbourhood is maintained by the young generation participants. It can be seen by observing the language use of the young generations 
at home and public domain. The third, the young generations of Sasak people in Surya Bhakti neighbourhood have proficiency to speak Sasak language fluently and accurately than Sumbawanese. It is because they prefer Sasak language than Sumbawanese whether they are at home and public domain or in their community. The last, the old generations of Sasak people in Surya Bhakti neighbourhood are more likely to use Sasak language than Sumbawanese when having daily communication to Sasak people in their community, even outside of the neighbourhood.

\section{AUTHOR'S STATEMENT}

The author declares that this article has never been published in any journal.

\section{REFERENCES}

Bianco, J. Lo. (2017). Policy activity for heritage languages: Connections with representation and citizenship. In Heritage language education (pp. 53-70). Routledge.

Brehmer, B. (2021). Maintenance of Russian as a heritage language in Germany: A longitudinal approach. Russian Journal of Linguistics, 25(4), 855-885.

Dana, L. P. (1999). Entrepreneurship in Pacific Asia: Past, Present \& Future. World Scientific.

Habtoor, H. A. (2012). Language Maintenance and Language Shift among Second Generation Tigrinya-speaking Eritrean Immigrants in Saudi Arabia. Theory \& Practice in Language Studies, 2(5).

Harnish, D. (2011). Tensions between adat (custom) and agama (religion) in the music of Lombok. Divine Inspirations: Music and Islam in Indonesia, 80-108.

Holmes, J., Roberts, M., Verivaki, M., \& AIPOLO, 'ANAHINA.' (1993). Language maintenance and shift in three New Zealand speech communities. Applied Linguistics, $14(1), 1-24$.

Irwandi, I. (2020). Implementing Eclectic Method for ELT through Distance Learning during the Covid-19 Pandemic. Educatio, 15(2), 91-103.

Jazadi, I., \& Widari, I. (2019). The Concerns, Roots, and Challenges of Islamic Culture in Sumbawa and Their Implications for Implementing Halal Tourism. KARSA: Journal of Social and Islamic Culture, 27(1), 52-74.

Kuncha, R. M., \& Bathula, H. (2004). The role of attitudes in language shift and language maintenance in a new immigrant community: A case study. Artikel, Tidak Diterbitkan.

Matras, Y. (2020). Language contact. Cambridge University Press.

Pong, L. T. (1998). Qualitative research methods in family medicine. Hong Kong Practitioner, 20(6), 305-306.

Prochazka, K., \& Vogl, G. (2017). Quantifying the driving factors for language shift in a bilingual region. Proceedings of the National Academy of Sciences, 114(17), 4365-4369.

Purwoko, B. (2016). Bureaucracy and the Politics of Identity: A Study on the Influence of Ethnicity on the Bureaucrat Recruitment Process in Sorong Selatan Regency, West Papua, Indonesia. Jurnal Studi Pemerintahan, 7(4), 516-550. 